Please refer to the definitive version of this article when citing:

Jensen, M.T., Scarles, C. \& Cohen, S.A. (2015). A multisensory phenomenology of interrail mobilities. Annals of Tourism Research, 53, 61-76, DOI: 10.1016/j.annals.2015.04.002

\title{
A multisensory phenomenology of interrail mobilities
}

\author{
Martin Trandberg Jensen \\ Department of Culture and Global Studies, Aalborg University, Denmark
}

Caroline Scarles

Scott A. Cohen

School of Hospitality and Tourism Management, University of Surrey, Guildford, UK

\begin{abstract}
This paper suggests that phenomenological studies of tourism mobilities can be informed by nonrepresentational approaches. We extend recent developments in sensory tourism research and nonrepresentational works to argue that methods upon which tourism researchers have long relied require 'pushing' or merging in previously underutilised ways that support these emerging areas of study. As a result, this paper embraces embodied methodologies. It integrates audio-visual impressionistic tales and netnographic snippets to shape its multisensory exploration of an under-researched European tourism and train travel phenomenon, interrailing. Our analysis exemplifies how the rhythmscapes and soundscapes of everyday rail travel inform the experience of interrail. Finally, we introduce the concept of thermalscapes, giving attention to the relatively neglected role of temperatures in tourism experiences.
\end{abstract}

Keywords: Non-representational; Rhythms; Sounds; Temperatures; Audio-visual methods; Interrail 


\section{Introduction}

"You must learn to heed your senses. Humans use but a tiny percentage of theirs. They barely look, they rarely listen, they never smell...But they talk, oh, do they talk."

Scott, M., The Alchmyst, 2007, p. 149

Modern tourism is often viewed as constitutive of modernity's mobility (Larsen, 2001). It has been argued that train travel dilutes travel sensations (Schivelbusch, 1986). Drawing upon Boorstin (1987) and Buzard (1993), Larsen (2001, p. 83) notes how: "the tourist who sat inside the train ceased to be a traveller, a sensuous subject, and became, as noted in the popular metaphor of the century, a mere 'parcel': a blind object, who was only thinking about arriving at her/his destination, arriving as s/he left, untouched by the space traversed." Others situate the narratives of rail spaces outside of the normal routines and practices of everyday life (Kirby, 1997), or within behaviouristic frameworks (Givoni \& Rietveld, 2007), reducing rail travel to a symbolic experience or a mere linear transport function.

In recent years, however, tourism mobilities research has questioned such claims, providing examples of how tourism mobility is not only a trivial question of overcoming distance; it is also a way of being in, sensing and experiencing various landscapes (Larsen, 2001; Roy \& Hannam, 2013). Whilst these contributions have arguably worked to showcase the performative and nonrepresentational dimensions of mobility, others have cautioned such approaches for generating an “overanimated [sic] mobile subject” (Merriman, 2014, p. 177). Indeed, waiting, slowness and even boredom can be just as important to 'mobile situations' as can those of speed, excitement and exhilaration (ibid.). This reminds us that immobilities, fixities and moorings, such as platforms, management systems and rail lines, configure and enable mobilities in the first place (Adey, 2006; Hannam, Sheller, \& Urry, 2006).

With these reflections in mind this paper offers three primary contributions. Firstly, we interrelate sensuous tourism research (Crang, 2003; Crouch \& Desforges, 2003; Edensor, 2007a) and non-representational approaches (Xiao, Jafari, Cloke, \& Tribe, 2013) to further inform tourism mobilities research (Hannam, Butler, \& Paris, 2014). More specifically, this contribution derives from the novel application of a multisensory phenomenology inspired by the experimental aspirations of research framed within non-representational theory (NRT), to an under-researched tourism and rail travel phenomenon: interrailing (Fernandes, Sarmento, \& Matias, 2013; Johnson, 2010; Klingbeil, 1994). Secondly, to meet this end we originally employ audio-visual impressionistic tales (Van 
Maanen, 1988; Vannini \& Taggart, 2013) and netnographic insights (Kozinets, 2010) to inform the understanding of tourism mobilities. We do so in response to suggestions that there is a: "narrowness in our understanding and representation of tourism" (Tribe, 2008, p. 924). Contributing to recent research that has adopted embodied methods as an opportunity to engage with and explore multisensual experiences (Bissell, 2010; Edensor \& Holloway, 2008), this approach draws on the first author's own travel experiences as well as interrailers' perspectives to elucidate the rhythmscapes (Edensor \& Holloway, 2008; Rantala \& Valtonen, 2014) and soundscapes (Duffy, Waitt, GormanMurray, \& Gibson, 2011; Waitt \& Duffy, 2010) of interrailing. Lastly, a further contribution to knowledge emerges as we focus on the sensuous influence of temperatures in this context, proposing the concept of thermalscapes to inform the relatively neglected role of temperatures in tourism research.

Each of these will be addressed as the paper first elaborates on the representational efforts embedded in the phenomenological tradition in tourism research. Secondly, it then clarifies the links between NRT and phenomenology to construct the conceptual framework for a multisensory phenomenology. Thirdly, in the spirit of the opening quote and of recent developments in embodied methodologies, the paper then provides an empirical exposition of interrail which animates representations by rendering a sense of place, and a poetics of movement, in a way which words alone would fail (see for example Latham \& McCormack, 2009; Scarles, 2010; Vannini \& Taggart, 2013). Similar to other attempts integrating data via hyperlinks in publications (Tribe, 2008) we recommend reading this paper in its electronic version, with an internet connection, in order to access some of the empirical material. Hyperlinked examples are followed by an audio symbol (ס) or a video symbol $(\bullet)$. To gain access to these, click on the underlined sentence (while holding down the ctrl button).

\section{NRT, phenomenology and embodied methodologies in tourism research}

Phenomenology has been widely used with the aim of exploring the meanings, understandings and textual interpretations constituting the phenomena under study (Pernecky \& Jamal, 2010), thereby attempting to: "reveal some enlightening...insights...through a systematic attempt to uncover and describe the structures and the meanings of a lived experience" (Curtin, 2006, p. 303). Drawing on symbolic interactionism (Hayllar \& Griffin, 2005; Masberg \& Silverman, 1996; Uriely \& Belhassen, 2006), such an approach reveals apparent significances through interviews and language — most often respondents' reflections with regards to destinations or events. Accordingly, the traits of social constructivism preoccupy phenomenology with the aim of identifying structures 
of symbolic meaning and sociocultural significances (Andriotis, 2009; Li, 2000). A majority of tourism phenomenologies consequently carry a trace of "representationalism, or, discursive idealism" (Dewsbury, Harrison, Rose, \& Wylie, 2002, p. 438) through which the key focus is on what things symbolise - what they denote and connote, what codes they inform, what values they defer and refer to (Vannini, n. d.).

Providing a different approach, this paper extends a range of recent tourism contributions that have sought to enrich the 'traditional' methodological reliance on interviews, surveys or focus group discussions. This includes the integration of sensory ethnography into visual tourism research (Scarles, 2010); studying via the senses the ways of embodying and identifying Britishness in Spanish charters (Andrews, 2005); describing the crafting of places through smells (Dann \& Jacobsen, 2003); and reflecting on the role of reflexivity and confessional writing styles to acknowledge bodily sensations during research (Cohen, 2013). Recently, the 40th anniversary editorial of Annals of Tourism Research called for further attention to the "embodied emotions, performances and affects that are an integral part of being tourist" (Xiao et al., 2013, p. 373).

Contributing to this current of critical sensory research, this paper contends that the prevailing symbolism and textual interpretation in tourism phenomenologies can be further developed to shed light on "...how life takes shape and gains expression in everyday routines, and sensuous dispositions" (Lorimer, 2005, p. 84; Obrador Pons, 2003). Thus, we propose that understanding, appreciation and engagement with multisensual and performative spaces of touristic experiences can be further enriched by extending existing applications of phenomenology to embrace the opportunities afforded by non-representational approaches to being in the world, and it is towards these we now turn.

\section{Multisensory phenomenology: intertwining phenomenology and the non-representational}

"It is striking that despite the overwhelming geographical focus of space as text or symbolic representation, the most common spatial experience is that sensed through everyday life."

Edensor, 2007b, p. 206

Multisensory phenomenology draws on a Merleau-Pontian ( 1962) reading of phenomenology that emphasises the sensing body as the primary site of knowing the world. From this perspective, multisensory phenomenology is intimately linked to more recent non-representational approaches as it understands lived experiences as based upon a composition of practical and embodied subjectivities 
(Anderson \& Harrison, 2010). Indeed, as Cadman (2009) and Waterton (2012) argue, nonrepresentational geographies have been heavily informed by Heideggerian and Merleau-Pontian engagements with phenomenology which propose that we are always-already thrown into the world and inseparable from it. Along these lines, multisensory phenomenology focuses on situated events, affective states and everyday performances (Vannini, 2015 ; Wylie, 2005), which in effect:

“...takes representation seriously; representation not as a code to be broken or as an illusion to be dispelled rather representations are apprehended as performative in themselves; as doings. The point here is to redirect attention from the posited meaning towards the material compositions and conduct of representations."

Dewsbury et al., 2002, p. 438

By drawing attention to the non-representational, phenomenologies of tourism cannot be treated as discursive constructs through minds devoid of corporeality (Carolan, 2008). Rather, focus falls on the sensuous, the affective and the everyday practices of tourist experiences. In the context of such constructivism and relationality, multisensory phenomenology entails a situated, sensuous and nonrepresentational epistemology. Ingold (1995, p. 58) asserts that something: “...must be wrong somewhere, if the only way to understand our own creative involvement in the world is by taking ourselves out of it". This reminds us that material and affective realms must also become visible to the body before we can conceive of them. Yet such corporeal shift requires new modes of rendition and engagement. In this respect, multisensory phenomenology draws upon the experimental tenets associated with NRT which seek to animate and enliven representations in artful and creative ways (Latham \& McCormack, 2009; Shortt, 2013; Vannini, 2015).

In tourism research the relational bodies that populate multisensory phenomenology link to Edensor's conceptualisation of 'touristscapes' (Edensor, 2007b). This spatial notion allows for critical explorations of the everyday, familiar spaces of habits, routines and sensuous dispositions constituting tourism phenomena. Hence, touristscapes conceptualise space as a "concrete and sensuous concatenation of material forces" (Wylie, 2002, p. 251), which possesses an agency to impact upon those who dwell and move within it (see also Ahmed, 2004; Bissell, 2010; Massumi, 2002). Building on this, Edensor (2007b) suggests that it is the temperatures, atmospheres, smells and sounds that encourage humans to specific courses of action. Aligned to the multisensory framework of this paper, we adapt the idea of touristscapes to explore three particular sensescapes that inform tourism: rhythmscapes, soundscapes and thermalscapes. 


\section{Researching through rhythms, sounds and temperatures}

In order to investigate the concept of rhythms, or rhythmscapes, research has principally drawn on Lefebvre's seminal work on rhythm-analysis (2004). Here, Lefebvre identifies how the everyday is comprised of intersecting rhythms, including isorhythmic (repetitive) and arrhythmical (irregular) flows. Importantly, such rhythms are conceptualised as imposed upon subjects, but equally organic and experienced through the living body. Inspired by this work, Edensor and Holloway (2008) unravel the rhythmic qualities of taking a coach tour by highlighting the carnal experience of both mobility and situatedness, and the ways in which they are blended through rhythms. Focus has also been given to the travel disorientation induced by rhythmical transitions (Anderson, 2015), and the rhythms of sleeping in nature (Rantala \& Valtonen, 2014). At a conceptual level, rhythm has been proposed as a central dimension within a larger framework for a politics of mobility (Cresswell, 2010). Rhythms, Cresswell argues, have the quality of bringing to mind a phenomenology of mobility as simultaneously organic, lived, and endogenous and exterior, imposed, and mechanical.

Soundscapes, like rhythmscapes, are central to lived experiences. Sound, however, is often reduced to the discursive, and in this reduction, the material relations present in our experience of sound are not fully attended to (Simpson, 2009). Some exceptions are Duffy et al.'s (2011) exploration of the embodied role of listening in connecting festival spaces and people, and Hannam et al.'s (2014) exemplification of how the noise of fieldwork recordings is an important part of making findings more intelligible and sensible. Accordingly, sonic spaces are not merely places where the subject comes to make her/himself heard, on the contrary, every place can be seen as a sonorous subject insofar as sound resounds there (Blesser \& Salter, 2007). Kanngieser (2012) argues that auditory reverberations and reflections have place-producing qualities, as auditory flows are folded through the material densities and gaps modulating and refracting sounds and voices in peculiar ways. Yet, whereas we know much about "measuring acoustic processes and sensory detection, we know less about the phenomenology of aural space" (Blesser \& Salter, 2007, p. 11).

Intersecting both rhythmscapes and soundscapes is the centrality of what we term thermalscapes. This particular scape focuses on the role of temperatures, a sensuous domain only marginally touched upon in relation to tourism (Edensor, 2007b). Studies on tourism and temperatures focus predominantly on travel decisions (Gössling, Bredberg, Randow, Sandström, \& Svensson, 2006; Maddison, 2001), the perception of weather and expected comfort levels (Mansfeld, Freundlich, \& Kutiel, 2007) and on larger links between tourism and the climate system (Gössling, 2002; Martin \& 
Belén, 2005). Our multisensory phenomenology, however, sees tourism as always emplaced in thermal environments in which bodies, materials and practices are ordered, influenced and affected by temperatures (McCormack, 2008).

Set in the context of interrail, the exploration of these three intermingled sensescapes allows for an original multisensory phenomenological approach to emerge. To illustrate how we engage with such aims in practice, we now turn to the context and methodology underpinning this study.

\section{Context and methodology}

Backpacking around Europe is often closely related with 'interrailing' (Johnson, 2010). The Interrail concept, or for non-European travellers, Eurail, dates back to 1959 when the first Eurail pass was distributed. Eurail global passes can be purchased by non-European residents and cover 24 European countries, whereas the Interrail global pass, for European citizens, enables train travel in 30 European countries. Global passes come in a variety of types ranging from ' 10 day passes' to up to three month continuous passes. Originally set in pro-European political landscapes, ingrained with visions of free movement and the narrowing of national jurisdictions, the interrail concept was born to support intercultural exchange between primarily young travellers. Today interrail is predominantly used by Western European and relatively young travellers, but also include families and senior travellers (Eurail representative, personal communication, 22-07-2014). Importantly, interrail is not an isolated rail travel experience but is enmeshed in the everyday life on the longestablished European rail network, as pass-holders travel on the same trains and routes as 'locals', commuters and other tourists. In this sense, the ordinary and mundane 'seep into' and inform the travel experiences of interrailing as touristic and everyday spaces become blurred (Franklin \& Crang, 2001). In these contexts, 'spotting' interrailers is most often associated with the observation of particular travel practices (such as filling-in interrail passes, wearing interrail armbands or studying the interrail rail map of Europe). Yet while the phenomenon is imprinted in the minds of three generations of Western travellers, the phenomenology of the actual rail experiences have been left largely untouched in favour of more enclavic backpacking theorisations, leaving out the more dynamic and everyday features of rail travel (Johnson, 2010).

\section{From fieldnotes to impressionistic tales}

Macbeth (2001) and Feighery (2006) argue that positional reflexivity is central to understanding how analysis is shaped. The empirical part of this paper is based upon a research project exploring 
the role of senses and affects in interrail experiences. Its ethnographic findings derive from two sources, multi-sited ethnography and netnography, which we intertwine in presenting the paper's empirical material.

Firstly, we draw on the lead author's travel experiences deriving from three months of multisited ethnography covering 28,000 km of rail lines across 23 European countries in June-August, 2013. These reflective narratives, voiced as 'impressionistic tales' (Van Maanen, 1988), derive from a European and relatively young, white male perspective, who had interrailed twice, in 2007 and 2013, leading up to the main fieldwork. Whilst we recognize that issues such as gender and age directly influence the role of the multisensory experience of interrail (and indeed deserves further attention), our impressionistic tales are limited to the in-depth and multimodal experiences of the lead author, whose age mirrors rather closely that of the majority of interrail pass-holders. To nuance these understandings, conversations and interviews were conducted with a range of interrailers of different gender and ages, to provide insight into the wider range of experiences by fellow travellers. The fieldwork was carried out during the interrail high season and covered the majority of, as well as most frequently travelled, interrail countries in continental Europe. As such, this reflexively informed ethnographic account unfolded as a fusion of first-hand experiences, ephemeral travel conversations, observations and audio-visual recordings (for their ability to enrich the representation of multisensory spaces). The stories and themes emerging from this work were documented through extensive fieldnotes written during train travel, or during late evenings and early mornings at various transit points (such as hostels, platforms and cafés), and were made with the research aims in mind.

Rather than representing these experiences as traditional textual and first-person fieldnotes, we draw on impressionistic tales (see Van Maanen, 1988) and the imaginary potentials associated with such a writing style (Vannini \& Taggart, 2013). Allowing the actual travel experiences of the lead author to be animated through the second-person, 'you', seeks to induce in the reader a suspended reading that stimulates memories from the past, inducing the multiplicities of personal origins to the tales told (Bachelard, 1958). Inspired by the reflexive turn in the ethnographic tradition (Clifford \& Marcus, 1986; Geertz, 1973), the aim of impressionistic tales is then to draw the audience into an (un)familiar story and allow the reader, as far as possible, to see, hear, and feel what the fieldworker saw, heard and felt in order to generate reflexive interpretation of embodied experiences (Scarles, 2010). As representation is almost always on the side of the one who looks, this reporting style seeks to: "...re-mark the performative possibilities of writing itself. The act of writing towards disappearance, rather than...toward preservation" (Phelan, 1993, p. 148). Consequently, readers 
become 'imaginative voyagers' (Scarles, 2009, p. 472) enlivening representations and making places legible. This seeks to make "the world come alive, and to give it back its sensuous performativity, the very performativity that much too often traditional research sucks away" (Vannini, 2012, p. 28).

In practice, six impressionistic tales have been 'written up'. Each arises from a combination of fieldwork experiences as well as post-hoc reflections on the sensory traits (such as warm compartments, smells or the feeling of fatigue) that were collectively performed as interplays between interrailers and everyday travellers. Whilst other tales could have been used, we selectively recalled these six impressions for their ability to animate multisensory spaces of interrail which were recurrent conversational topics during the fieldwork. The tales are used as a representational means of cracking open the non-representational and affective spaces of interrail. The tales intertwine audio-visual material (via YouTube and SoundCloud) collected during train travel and use these rich examples to capture the inherent multisensuality of experiences in ways that discrete methods would not allow. Through these recordings we are less concerned with what meaning we can discern from the combination of sounds and sights. Rather voice should be given to the complex relations between sound, thus listening to “...its materiality, rhythm, and timbre, and how this resonates in us" (Simpson, 2009, p. 2571) and overwhelms us through a variety of affects. This relates to geographical work (Kanngieser, 2012) suggesting that an 'acoustic politics of space' is cogent in times when "affect contaminates empirical space through language" (Massumi, 2002, p. 62). That said, however, a key aspect of our argument is that the lived body cannot be treated through discrete senses. It is, from the first, a perceptive body (Sobchack, 1992).

\section{Netnography and the tales of other travellers}

In order to access the nuances of the impressionistic tales, the analysis also draws on netnography, which remains an underutilized method in tourism research (Mkono \& Markwell 2014). The paper employs 'archival netnographic data' (Kozinets, 2010, p. 104) of the Interrail Facebook Group, spanning 2008-2014. The lead author did not actively participate in the online forum from which data is gathered, rather forum conversations were continuously studied, and 53 statements concerning the role of the senses during interrail travel were collected and analysed through a thematic analysis of recurrent themes (Beaven \& Laws, 2007; Mkono, 2011). Through this process the data was organised around three themes relating to interrailers' accounts of rhythms, sounds and temperatures. The final step involved weaving together the netnographic snippets, which are all represented anonymously through the use of pseudonyms, with the audio-visual impressionistic tales. 
The paper's findings are presented in this interwoven manner, so as to enrich the impressionistic tales by illustrating the routines and ad-hoc practices of interrailers.

Our main intention in integrating audio-visual impressionistic tales and netnographic insights is to demonstrate how non-representational concerns can inject into phenomenologies a willingness “...to experiment with established, indeed quite traditional, methods to create innovative, insightful methodological hybrids" (Latham, 2003, p. 1993). As such, this work is intended to pave a route for further methodological experimentation in tourism research. With these considerations in mind, the following findings illustrate how a multisensory phenomenology of interrail unfolds.

\title{
Rhythmscapes
}

\begin{abstract}
Envision yourself having travelled thousands of kilometres on primarily regional trains across Europe. Now, you find yourself standing in front of your first high-speed rail experience, boarding the TGV train in Lyon heading towards Paris. Paradoxically, a few minutes afterdeparture you find yourself nauseous. Next to you, a recently purchased bottle of water stands. You look at the bottle, observing its gentle movements aligned to those of the train. Besides this, there are few indicators of movement. No repetitive bumps on the tracks; no soft swaggering from side-to-side; no roaring diesel engine (everything runs on electricity here). Sitting there, you think back to the regional train, a few days prior, between Bologna and Milan. You evocatively picture your water bottle at that time, speaking back to you through frantic movements to the life of compartment curtains
\end{abstract}

Impressionistic tale, August, 2013

Coordinated through the states of the railway, the types of seats available, the train machinery, the range of situated materialities and sensing interrailers, particular rhythmscapes are produced. On one occasion, an interrailer who was forced to take motion sickness medication was suffering from increasing nausea due to the subtle, monotonous movements of the train carriage. In many others incidences, the gentle motions of the train, the relaxed atmosphere in the compartments, and the steady crossing of large distances, softly rocked interrailers, and many other train travellers (Picture 1), to a much-needed rest, underlining how mundane rail space 'seeps into' the travel experiences of interrailers (Franklin \& Crang, 2001). 


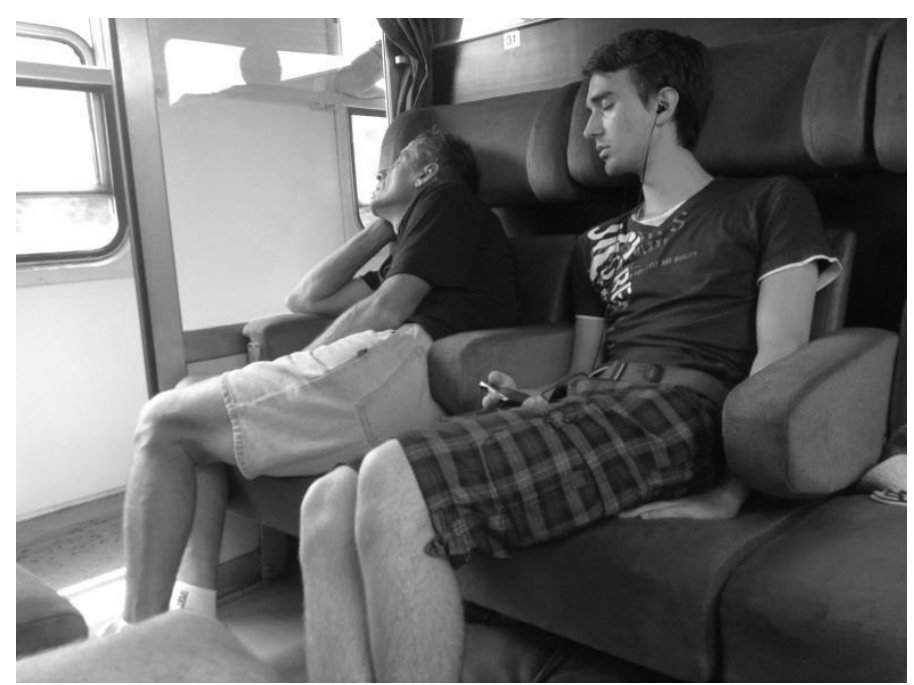

Picture 1 Blurred touristic/everyday space-young interrailer and local.

Thus, rhythms are integral to the spatio-temporal experience of interrail. This supports Anderson's (2015) observations that travel (dis)orientation occurs as the holistic consequences of leaving one set of socio-spatial relations and moving to another. As 'transient outsiders' (Meethan, 2003), interrailers seldom acquire the crucial knowledge and understanding of local travel practice in ways that locals do, and this leads to rhythmical discontinuities. In practice, this manifests as interrailers move inbetween transient spaces including the specific pulse of urban experiences to the rhythmical consistencies of particular trains; it occurs during the immobilisation of waiting time, delays and cancellations at train stations; and in the moments of being late, franticly navigating train stations to find departure platforms in time.

Yet rhythms are also embodied through subtle, playful travel practices. Louise (Facebook, 2709-12) explains how they killed travel time by playing a game of: "Trying to figure out signs we're passing by full speed". This practice materialises as vivid head movements from side to side and flickering eyes trying to determine the signs passed. In the composition between the speed and materiality of the train, the interrailer and the frequencies and intervals of signs, rhythm is embodied and co-produced. This is an everyday example of how rhythms organically emerge from the: "emplaced engagement with the material, sensory, social and cultural contexts in which we dwell" (Pink, 2007, p. 62). The crucial point here is that in the rhythms of 'doing tourism', much of what is done does not represent a symbolic order or phenomenological 'essence' of practice (Anderson \& Harrison, 2010). In this respect, multisensory phenomenology, informed by the non-representational, allows for the exploration of everyday spaces constructed through representation as embodied performances, animated through novel methodological hybrids. 
This impressionistic tale also shows how: "Each rhythm is folded with a series of forces, materialities, sensations and visual registers, marshalled through multiple corporeal and incorporeal, human and non-human assemblages that take on different intensities, speeds and textures through different phases and spaces" (Edensor \& Holloway, 2008, p. 499). By studying how rhythms are dispersed onto things it illustrates how research can study materialities "as one listens to a symphony, an opera" (Lefebvre, 2004, p. xii). In order to further understand the affective and subtle engagements with rhythms, we argue that the tenuous 'pulses' of mundane materialities (see the audio-visual recordings of curtains, coat hangers and cables) merge with subjective apprehensions wherein time can appear to slow down, speed up or disorder habituated rhythms (Edensor \& Holloway, 2008). From such a perspective rhythm is both mediated and governed by technologies and in contact with what is least rational in human beings, the lived, the carnal, the sensing body (ibid.).

The impressionistic account also illustrates how the experience of rhythm can be disorienting due to the subtle juxtaposition of the embodied rhythm of (regional) train travel and the "mechanical velocity' (Larsen, 2001, p. 83) and the apparent rhythmlessness of the TGV train. Anderson (2015) reminds us how bodily rhythms exhibit a kind of lingering memory which resist change and, to keep you running smoothly, cling to the same old familiar schedules of movement. When habituated rhythmscapes are altered, rhythmic discords are confronted at the transition stage (Edensor \& Holloway, 2008). Sara (Facebook, 15-09-11) provides a rich recall: "Night train from Venice to Budapest. Had five passport and ticket checks during the night, ranging from midnight to $4 \mathrm{am}$. Saw two backpackers escorted off the train by police. Not exactly the most pleasant/comfortable journey in the world". Long-term immobilisations during border crossings, or abrupt interruptions of passport controls on night trains, create rhythmical disjunctions that interrailers experience repeatedly, serving as reminders that mobilities are indeed regulated by institutional fixities, surveillance systems and control (Adey, 2004, 2006).

In tiring occasions of train travel, interrailers were seen staring absent-mindedly at a range of nearby materialities, rhythmical mediators which induced relaxed or even meditative states of travel. This relates to the act of gazing or glancing out compartment windows (Larsen, 2001), another habitual practice of interrailers.

Envision yourself en route to Austria, through Northern Italian landscapes. As the train runs parallel to some electricity cables, the rhythmical synchronicity of the cables, as experienced through the moving train, produces a waved line that together with the situated sounds encapsulate a particular embodied rhythm. On other days, other routes, different atmospheres, try to imagine daydreaming on grey days. Tranquil and 
comforted by the sounds and movements of rain drops carving their way across windows . Imagine daydreaming, thinking back on travel experiences, listening to music, with eyes fluctuating to follow the numerous rain drops as they transversally move across the transparent surface.

Impressionistic tale, July, 2013

Through audio-visual accounts of electricity cables and rain drops, we show how a multisensory phenomenology animates materialities through the lived ambience, tempo and repetitions emplaced in interrail and rail travel in general. Borrowing Lefebvre's (2004) terminology, the first example showcases the repetitive, almost isorhythmic movements of the electricity cable. We go on to show how raindrops on compartment windows arrhythmically co-generate a situated rhythmscape interwoven with the subtle movements of the train and the affective geography of the localised experience. These empirical characterisations also illustrate how interrail is enwritten into the very banal experience of everyday rail travel and is constructed through the complex coordination of embodied, materially informed and technologically mediated rhythms, repetitions and frequencies. This reminds us that while the train indeed does provide a cinematic vision which interjects a particular spatio-temporal image (Haldrup \& Larsen, 2009), it does not "impoverish the other senses" (ibid., p. 72), but continuously rearranges the ways through which the perceptive body registers. To further strengthen this multisensory claim, the following section explores the intermingled role of soundscapes.

\section{Soundscapes}

Envision yourself on a night train, more specifically the IR383, leaving Bucharest, Romania, every day close to midnight, commencing its 10-hour journey towards the capital of Bulgaria, Sofia. Imagine having waited for hours at the station, and now increasingly tired you find yourself craving to catch some sleep. As the train cuts through the darkness of the countryside, you take off your shoes; perhaps you use your jacket as a blanket; perhaps you jam some shirts together to form a temporary pillow, and with an exhausted, slightly despairing sigh, you make a wriggle, and find yourself positioned for an ephemeral rest. The compartment is silent, and the only auditory evidences of movement are the sounds of the train moving through the night $^{\text {J }}$. Sleeping only vaguely, the repetitive sound reminds you that you are indeed on the way_-moving — which, after all, makes up a redeeming thought. At 2 am the train is suddenly put to a halt. The deadening of sounds leaves a strangely noiseless and uncertain atmosphere in the wagon. You notice your fellow travellers move their heads, groggily glancing with half-open, dreary eyes, as if to reorient themselves on the sudden immobilisation. As the train departs, the compartment is once again enrolled into 
the monotonous sounds of the rolling train, complemented by the heavy breathing of travellers and the opening and closing of the automatic sliding doors.

Impressionistic tale, July, 2013

A central dimension of interrailing is negotiating the challenge and discomfort of night trains (see Pictures 2 and 3). In the previous audio file notice the vague creaking of the chassis, the metallic seething of the heavy train running across the rails; the uninterrupted rumbling and the on-going bumps of the wheels crossing each iron wielding of the railways. These are sonic forces that provide dimensions, attentions and imaginations to situated experiences. During nocturnal travel, perception goes well beyond the visual consumption of the objectified spectacle (Cook \& Edensor, 2014), and we exemplify how the complex entanglement of sound and sight nuances ocularcentric accounts of tourism. Across these monotonous spaces of 'doing nothing', which are fundamental parts of extensive interrail, Ehn \& Löfgren (2010) stress how one starts to 'see' the social and material surroundings in new ways. The tedious and habituated soundscape emerging from the train running across the rails provides a 'safe' sonic geography for sleep, yet as the train unexpectedly halts, it suddenly (re)activates the sensual consciousness of travellers. The transmission of affects occurring in such sudden auditory exchanges literally change the biochemical properties of travellers, and like in Bissell's (2010) work on rail mobility, this is seen through a variety of bodily predispositions; including adrenaline, tensed muscles and attentive audition. Thus, in line with the primary contribution of this paper, we see how a multisensory phenomenology complements symbolic and textual tourism phenomenologies through the employment of sensory and impressionistically attuned methodologies. 

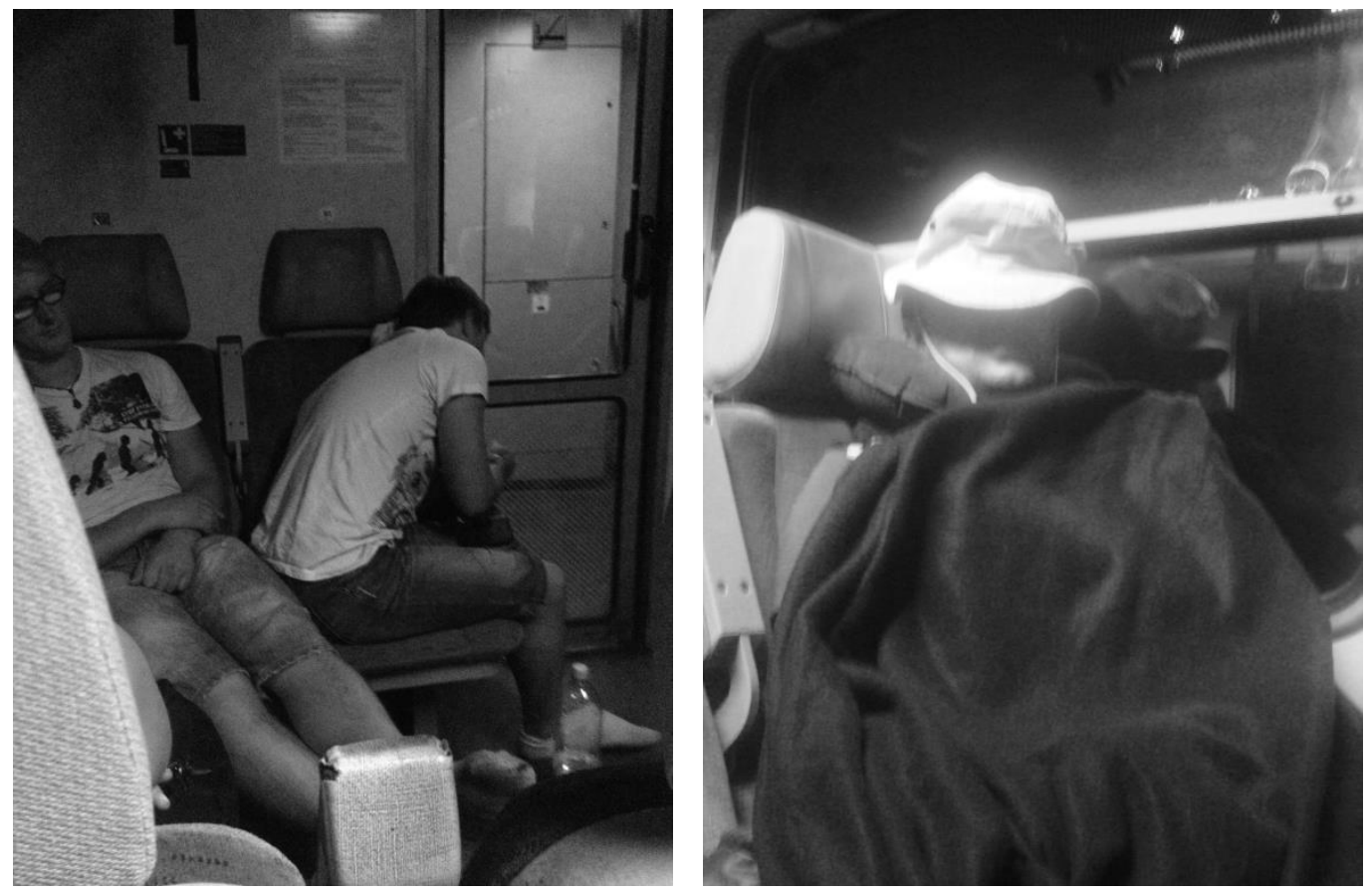

Pictures 2-3 Catching sleep (IR 383, en route to Bulgaria).

Thomas notes: "This year I have travelled in 3 German CityNightLines and it's impossible to sleep in those trains; uncomfortable, people, all the night, go up and down..." (Facebook, 26-08-12). Sharing somewhat similar experiences, Jason recalls: "I had some hours with a guy ...we had a real good talk, after he left the train, some fully drunk soccer fans bolted in and after a while I left to search for another place." (Facebook, 13-09-11). Besides illustrating the immanent multisensory nature of interrail, both examples emerge from frustrating sonic 'relations' with disruptive copassengers. This auditory sensitivity provides an alternative to discursive approaches, since social relations emerge through auditory (dis)engagements and expectations; it is an outcome of emplaced sonic forces (Conradson \& Latham, 2007). In this sense, soundscapes become a primary sensuous geography through which affects are produced and circulate, generating collective atmospheric states of relaxation, irritation, nervousness, playfulness and so forth (Ahmed, 2004). This is no different when sleeping in couchettes:

Picture yourself having fought your way to the top bunk-bed on a night trip from Belgrade to Skopje. Imagine that you are forced to keep the window open all night to allow for cooler air to stream inside, and doing so, also allowing for the sounds of the old regional train ${ }^{\cdot J}$ wagon bumping its way across the sturdy rail-lines; the signal horns sounding for each railway crossing passed (which are all too frequent on such regional train routes). Imagine how the otherwise dark compartment is experienced through the snoring, 
light coughing and sniffing of travellers you hardly know in the bunk beds underneath you, reminding you that you are not alone, and more importantly, that no one is tinkering with their (or your!) luggage.

Impressionistic tale, August, 2013

The audio file illustrates with what overwhelming force sounds embrace specific situations. Due to the open window the sounds from the machinery of the train is ear-splitting, the horn blowing is sudden and unsettling, and the wind moans. Some passengers materially negotiate these sonic situations by using headphones or earplugs, others 'bury' themselves under jackets or talk louder to make up for the noise. Such a soundscape is regularly experienced by interrailers when travelling in regional trains with open windows. On these occasions, audition is highly significant as it informs spatial understanding; the sense of arrival/departure, a sense of scheduled movement; and a sense of mobility and immobility. This exemplifies how the rhythms and sounds of interrail function empirically in tension between movement and mooring (Adey, 2006, p. 91; Hannam et al., 2006).

Soundscapes cannot be reduced to the study of 'sound' but are spatially, affectually and socially productive as they display different expectations, habits, practices and responses. Jonas recalls: "Worst is when you are sat next to someone chomping on crisps whilst rustling the packing in the dead of night, when everyone else is asleep" (Facebook, 13-09-11). Such auditory disturbance complements textual representations related to the widely neglected role of listening in tourism research (Duffy et al., 2011). The accounts illustrate the influence of sonic spaces on interrail interpretations, but within the aims of a multisensory phenomenology, also integrate impressionistic accounts and audio examples to enliven the sound of the non-representational, listening to spaces and how they resonate in us (Simpson, 2009). Through these examples, the paper proposes a 'sonic concern' to be further developed in audio-visual accounts in tourism. These neglected concerns bring us to another under-researched domain ingrained in all sensescapes, thermalscapes.

\section{Thermalscapes}

'They are treating us like animals!' an American woman cries out, aiming her outburst towards the train personnel, as the heat in the compartment continues to increase. It is late July, and the central-European summer is providing tedious temperatures around 40 degrees Celsius. Furthermore, the air-conditioning has stopped functioning. 'It happens every summer!' the conductor remarks, despairingly asking everyone to keep their windows shut, to avoid the hot air from outside interfering with the air-conditioning system. Some people have started taking off their shirts (some children dressed only in boxers), others have found unforeseen value in newspapers and train tickets 
enduring heat is leaving uncomfortable traces as sweat patches on shirts and trousers. The sighs and obvious corporeal struggles to find thermal comfort embrace the compartment in a sensuous collectiveness. You try to stand up, yet find yourself glued to the synthetic leather seat, in what seems to be a watery amalgamation between you and the seat. After hours of sighs and drowsy movements, the conductor decides to let all exit doors stay open during travel, which immediately creates a congregation of travellers standing at each door, refreshed by the wind.

Impressionistic tale, July, 2013

The sensuous is not solely an internal resource, but is dispersed as material traces (Picture 4). These traces are also perceptual experiences that impress upon the body, provoking yet other affective sensations (Edensor, 2007b). Accordingly, thermalscapes, as we conceptualise the term, are not just spaces through which bodies move, but instead a set of dynamic and kinetic affects. Temperatures, in other words, can be looked upon through their kinetic relations: differential pressure gradients and the velocity of molecules affecting its form (McCormack, 2008). But more important for this paper, temperature can be approached dynamically in relation to how it slows down, speeds up and alters human behaviour, moods and travel sensations. The video clip illustrates how a specific thermalscape creates collective performances of swaying newspapers and tickets through which travellers try to ensure thermal comfort. Also, in this example, the access to 'adequate' temperatures becomes a fundamental resource, a human right, materialising as a sensuous subject leading to discussions between both train personnel and travellers. This thermal influence is central to interrailing practices; e.g., frequently redressing to adapt to changing thermalscapes as trains cut through mountains, flatlands and urban landscapes, each with specific temperatures; sticking one's head out open windows, $g(r)$ asping for fresh air and cooler temperatures, and preparing oneself for extended travel with cold drinks, are all some of the embodied practices revolving around the subtle effects of particular thermalscapes. As a result the embodied knowledge informed by the sensuous apprehension of places generates a range of both unreflexive, conscious and instrumental touristscapes (Edensor \& Falconer, 2011).

Imagine the cold wind gusts circulating in compartments as trains cut through deep tunnels; imagine the variation of temperatures often leading to subtle coughs ${ }^{.}$. Or try to envision going to cramp, warm and foul-smelling toilets to freshen up, and soak yourself with cold water, following hours of perspiring train travel. Imagine unflushed toilets; imagine the distinct smell of urine building up as the toilet has been heated up during a whole day. Now picture yourself standing in front of the door, negotiating the extent to which your toilet desire in fact reasons you to go in there. Imagine taking a deep breath, and with a slightly disgruntled face, entering the room and locking the door behind you. 


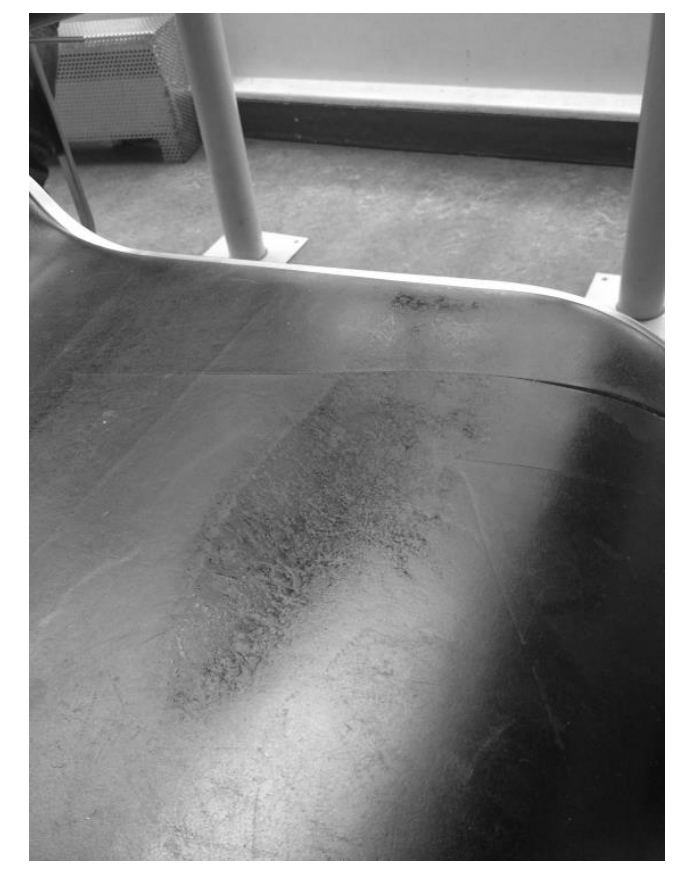

Picture 4 Material traces of thermalscapes.

A wide range of materialities thus moderate the experience of temperatures during interrail. These include for instance access to/and type of windows available, the amount of luggage dragged along and compartment thermostats (surprisingly few seem to work when needed!). In relation to this, Manuel exclaimed: "This compartment...where I slept last summer, between Nice and Paris. It had 7 passengers for 6 beds! And a dog! To end in beauty [sic], in the middle of the night, the air conditioning broke down..."(Facebook, 31-05-12). Next to this, Mary-Ann (Facebook, 21-08-09) recalls a vivid event: "You've had a 3 am start...you've had a dodgy McDonalds the night before and been sick. You still feel nauseous at 8 am when you are getting your first train at 6 that day to get from Nice to Barcelona. All the compartments are full besides one in which resides one woman who has the strongest stench of garlic, literally radiating from! During the journey, just to add a little salt to the wound, she gets up to not only shut the compartment door, but turn the air con off!!"

Enrolled into a range of sensations, these remarks all touch upon the centrality of thermalscapes, more specifically how air-conditioning systems and thermostats are material infrastructures through which temperatures can be negotiated or forced upon passengers. Hence, when air-conditioning systems breakdown, or when temperature is automatically imposed upon people, it reminds that space 
is transduced through electronic networks, design codes, hardware and operational management systems (Adey, 2006), which order and reorder the sensory contexts of rail travelers, interrailers included.

The influence of temperatures and tiresome travel also relate to olfactory sensations: "Sorry to be disgusting but; smelly feet" (Facebook, 21-09-09). Yet, the relational composition of sweating travellers need not necessarily imply negative consequences, and as Chloe sensually recalls: "Slept like a $\log$ curled up in a ball with sweaty Italian lads from Salzburg to Venice. Good times!!” (Facebook, 26-08-12). These accounts point towards perceptions of both 'disgusting and enchanting' experiences that appear to be partly generated through particular thermalscapes. As the examples have illustrated, the olfactory sense is a powerful register through which meanings, memories and sensations are produced. Building on Dann and Jacobsen (2003) who describe the crafting of places through smells, we intertwine the influential role of temperatures, to acknowledge the diverse, manipulating and influencing role of thermalscapes.

\section{Multisensory phenomenology: opportunities and constraints}

Having envisioned what interrailing entails, one might be able to picture through which sensuous geographies interrailers (make) sense (of) their rail experiences. In doing so we illustrate how tourism mobilities can be re-animated through multisensory phenomenologies that strive: "...to find inspiration in the arts, in the poetics of embodied living...in taking dedicated risks, in exercising passion, and in finding ways to re configure thinking, sensing, and presenting" (Vannini, 2015, p.14). Arguably, the sensory characteristics of places might change according to a whole range of internalities and externalities, yet the railway routes, the specificities of trains, compartments, as well as the range of moorings and spatial fixities such as platforms, stations and operational systems leave enduring contexts that produce places (Vannini \& Taggart, 2013). Our study has shown how interrail unfolds in the everyday of rail travel, and has exemplified how the multisensory cannot be reduced to 'the mobile', but traverse incidences of movement and rest, moorings and mobility. Inspired by the non-representational, multisensory phenomenology thus questions the symbolic claims that position rail space outside that of the 'normal' routines and practices of everyday life (Kirby, 1997), as well as wider discourses on tourism consumption as extraordinary, liminal, moments of experiencing (Farber \& Hall, 2007; Mossberg, 2008). Instead mobile spatialities have been woven into the everyday, as are notions of the monotonous, mundane or 'banal' (Binnie, Edensor, Holloway, Millington, \& Young, 2007). From such a perspective, ordinary actions and apparent insignificant 
subtleties, whilst providing little in terms of essentialist or symbolic meaning, still make a crucial difference to everyday experiences.

These contexts have been approached by integrating ethnographic reporting styles that reflect recent developments within non-representational work (Bissell, 2010; Vannini \& Taggart, 2013), which value the pre-cognitive as something more than an addendum to the cognitive. Methodologically, phenomenological research with a non-representational focus requires 'pushing' or merging methods in experimental ways to document the embodied practices and performances of travellers' experiences (Latham, 2003; Simpson, 2011). This questions the occularcentric domination of the visual in tourism studies (Crang, 1997). Yet, our attempt is not a resistance to the visual dominance in tourism research, but rather calls for further research to develop ways to enliven the immanent multisensory nature of the visual (Edensor \& Falconer, 2011; Scarles, 2010). For this, there remains a continuing paradox in attempts to theorise and to write about the body as existing outside our linguistic structures as this simultaneously, and inevitably, inscribes the body into those very same linguistic structures (Shusterman, 1997). Nonetheless, this paper has sought to narrow the divide between semantics and somatics, between words and bodies, through its audio-visual and impressionistic rendition. We recognise that critics may find phenomenology informed by nonrepresentational concerns: "obscure, opaque and unreachable in the current climate of scientisation, relevance and impact" (Xiao et al., 2013, p. 376). Yet for this same reason we have pursued an alternative mode of research concerned with "...the visceral experiences, atmospheres, vibes, emotions, and affective capacities that are currently mostly rendered inaccessible by the underlying philosophy of our current methodologies..." (ibid, p. 376). By adopting a reflexive style driven by a fusion of audio-visual impressionistic tales and netnography, readers have been urged to experience the three elaborated sensescapes as intimately linked. Through immersion readers were encouraged to carefully listen to the sounds, study the non-representational movements of the hand-held recordings, as well as imagine the olfactory remarks, the atmospheres and affects that the examples embrace.

Finally, in an effort to extend our understanding of such sensuous geographies, we furthermore developed Edensor's (2007b) observations in relation to the importance of temperatures. With this paper we suggest that thermalscapes are central sensuous geographies to further inform tourism studies. As has become clear through the analysis, temperatures configure and reconfigure experiences in ways that go beyond individual experience. Thermalscapes segregate, conjoin and influence the behaviour and affective experiences of travellers. Following McCormack (2008, p. 415) 
there is thus an 'animate agency' in temperatures, which means that the properties of the medium through which livings beings move are all-important. Acknowledging this allows tourism research to rethink the 'materialities' through which the sensing of mobilities is enacted.

\section{Conclusion}

This paper has illustrated how interrailing, as with all other tourism and everyday experiences, is a multisensory experience. Through three interlaced sensescapes - rhythmscapes, soundscapes and thermalscapes - the analysis hasdiscussed how interrail experiences are set in the everyday 'hum' of rail travel, complexly generated on the basis of mobilities and immobilities, and embodied through materially dispersed and technologically mediated rhythms, sonic spaces and thermal atmospheres.

The paper has demonstrated how phenomenology in tourism can be informed by sensuous concerns (Edensor \& Falconer, 2011) and non-representational approaches (Xiao et al., 2013). Whilst the paper extends recent contributions on the sensory in tourism (Edensor, 2007b; Scarles, 2010), its main contribution is the original application of multisensory phenomenology in the context of interrailing. The paper has been crafted with the hope that other scholars will extend this work, and benefit from the widening opportunities of digital publishing (integrating hyperlinks, audio, videos and so on) in academic journals, which are still relying primarily on textual representations.

Impressionistic tales and audio-visual examples have been used to animate representations multisensuously in the spirit of recent non-representational theorists (Latham \& McCormack, 2009; Vannini, 2015 ). Netnographic extracts were used to nuance the impressionistic tales, and to provide an emerging example of how the novel integration of methods can contribute to insights on tourism mobilities and beyond.

Finally, in introducing the concept of thermalscapes, our aim has been to encourage future studies to further investigate experiences as emplaced in, and experienced by temperatures. Further analysis of tourism thermalscapes will allow for insightful theorisations on the agentic role of varying, circulating and intervening temperatures in a variety of settings. Indeed temperatures act as a factor influencing the location of tourism, as a resource supporting a wide range of activities, and as an attraction in its own right (Martin \& Belén, 2005). Yet while the embodiment of temperatures is perhaps one of the most enduring and interceptive sensuous dimensions in tourism, its study oddly remains little more than a footnote in tourism research. 


\section{References}

Adey P., Surveillance at the airport: Surveilling mobility/mobilising surveillance, Environment and Planning A 36, 2004, 1365-1380.

Adey P., If mobility is everything then it is nothing: Toward a relational politics of (im)mobilities, Mobilities 1 (1), 2006, 75-94.

Ahmed S., The cultural politics of emotion, 2004, Routledge; New York.

Anderson J., Exploring the consequences of mobility: Reclaiming jet lag as the state of travel disorientation, Mobilities 10 (1), 2015, 1-16.

Anderson B. and Harrison P., Taking-place: Non-representational theories and geography, 2010, Ashgate.

Andrews H., Feeling at home Embodying Britishness in a Spanish charter tourist resort, Tourist Studies 5 (3), 2005, 247-266.

Andriotis K., Sacred site experience: A phenomenological study, Annals of Tourism Research 36 (1), 2009, 64-84.

Bachelard G., The poetics of space, 1958, Beacon Press; Boston.

Beaven Z. and Laws C., "Never Let Me Down Again"1: Loyal customer attitudes towards ticket distribution channels for live music events: A netnographic exploration of the US leg of the Depeche Mode 2005-2006 World Tour, Managing

Leisure 12 (2-3), 2007, 120-142.

Binnie J., Edensor T., Holloway J., Millington S. and Young C., Mundane mobilities, banal travels: Editorial, Social \& Cultural Geography 8 (2), 2007, 165-174.

Bissell D., Passenger mobilities: Affective atmospheres and the sociality of public transport, Environment and Planning D Society and Space 28 (2), 2010, 270.

Blesser B. and Salter L.R., Spaces speak, are you listening?, 2007, MIT Press; Cambridge.

Boorstin D.J., The image: A guide to pseudo-events in America, 1987, Vintage Books; New York.

Buzard J., The beaten track: European tourism, literature, and the ways to culture, 1800-1918, 1993, Oxford University Press.

Cadman L., Nonrepresentational theory/nonrepresentational geographies. Nonrepresentational theory/nonrepresentational geographies, In: Kitchen R. and Thrift N., (Eds.), International encyclopedia of human geography, 2009, Elsevier; London,

$456-463$. 
Carolan M.S., More-than-representational knowledge/s of the countryside: How we think as bodies, Sociologia Ruralis 48 (4), 2008, 408-422.

Clifford J. and Marcus G.E., Writing culture: The poetics and politics of ethnography, 1986, University of California Press.

Cohen S., Reflections on reflexivity in leisure and tourism studies, Leisure Studies 32 (3), 2013, $333-337$.

Conradson D. and Latham A., The affective possibilities of London: Antipodean transnationals and the overseas experience, Mobilities 2 (2), 2007, 231-254.

Cook M. and Edensor T., Cycling through dark space: Apprehending landscape otherwise, Mobilities (ahead-of-print) 2014, 1-19.

Crang M., Picturing practices: Research through the tourist gaze, Progress in Human Geography 21 (3), 1997, 359-373.

Crang M., Qualitative methods: Touchy, feely, look-see?, Progress in Human Geography 27 (4), 2003, 494-504.

Cresswell T., Towards a politics of mobility, Environment and Planning D Society and Space 28 (1), 2010, 17-31.

Crouch D. and Desforges L., The sensuous in the tourist encounter - Introduction: The power of the body in tourist studies, Tourist Studies 3 (1), 2003, 5-22.

Curtin S., Swimming with dolphins: A phenomenological exploration of tourist recollections, International Journal of Tourism Research 8 (4), 2006, 301-315.

Dann G. and Jacobsen J.K.S., Tourism smellscapes, Tourism Geographies 5 (1), 2003, 3-25.

Dewsbury J.D., Harrison P., Rose M. and Wylie J., Enacting geographies, Geoforum 33 (4), 2002, 437-440.

Duffy M., Waitt G., Gorman-Murray A. and Gibson C., Bodily rhythms: Corporeal capacities to engage with festival spaces, Emotion, Space and Society 4 (1), 2011, 17-24.

Edensor T., Sensing the ruin, The Senses and Society 2 (2), 2007a, 217-232.

Edensor T., Mundane mobilities, performances and spaces of tourism, Social \& Cultural Geography 8 (2), 2007b, 199-215.

Edensor T. and Falconer E., Sensuous geographies of tourism, In: Wilson J., (Ed), The Routledge handbook of tourism geographies, 2011, Routledge; New York, 74-81.

Edensor T. and Holloway J., Rhythmanalysing the coach tour: The Ring of Kerry, Ireland, Transactions of the Institute of British Geographers 33 (4), 2008, 483-501. 
Ehn B. and Löfgren O., The secret world of doing nothing, 2010, University of California Press.

Farber M.E. and Hall T.E., Emotion and environment: Visitors' extraordinary experiences along the

Dalton Highway in Alaska, Journal of Leisure Research 39 (2), 2007, 248-270.

Feighery W., Reflexivity and tourism research: Telling an(other) story, Current Issues in Tourism 9 (3), 2006, 269-282.

Fernandes C., Sarmento M. and Matias A., Evaluation of the Interrailers' Satisfaction Regarding the Tourism Services and Activities in Italy, Greece and Croatia, In: Matias Á., Nijkamp P. and Sarmento M., (Eds.), Quantitative methods in tourism economics, 2013, Springer; Berlin, Heidelberg, 59-78.

Franklin A. and Crang M., The trouble with tourism and travel theory?, Tourist Studies 1 (1), 2001, $5-22$.

Geertz C., The interpretation of cultures: Selected essays, 1973, Basic books; New York.

Givoni M. and Rietveld P., The access journey to the railway station and its role in passengers' satisfaction with rail travel, Transport Policy 14 (5), 2007, 357-365.

Gössling S., Global environmental consequences of tourism, Global Environmental Change 12 (4), 2002, 283-302.

Gössling S., Bredberg M., Randow A., Sandström E. and Svensson P., Tourist perceptions of climate change: A study of international tourists in Zanzibar, Current Issues in Tourism 9 (45), 2006, 419-435.

Haldrup M. and Larsen J., Tourism, performance and the everyday: Consuming the orient, 2009, Routledge; New York.

Hannam K., Butler G. and Paris C.M., Developments and key issues in tourism mobilities, Annals of Tourism Research 44, 2014, 171-185.

Hannam K., Sheller M. and Urry J., Editorial: Mobilities, immobilities and moorings, Mobilities 1 (1), 2006, 1-22.

Hayllar B. and Griffin T., The precinct experience: A phenomenological approach, Tourism Management 26 (4), 2005, 517-528.

Ingold T., Building, dwelling, living: How animals and people make themselves at home in the world, In: Strathern M., (Ed), Shifting contexts: Transformations in anthropological knowledge, 1995, Routledge; London, 57-80.

Johnson J., Euro-railing: A mobile-ethnography of backpacker train travel, Beyond Backpacker Tourism - Mobilities and Experiences 2010, 102-125. 
Kanngieser A., A sonic geography of voice towards an affective politics, Progress in Human Geography 36 (3), 2012, 336-353.

Kirby L., Parallel tracks: The railroad and silent cinema, 1997, Duke University Press; Durham.

Klingbeil P., Backpacker's rail card: Passport to Europe, Forum-Council of Europe 2, 1994, 24-25.

Kozinets R.V., Netnography: Doing ethnographic research online, 2010, Sage Publications; Los Angeles.

Larsen J., Tourism mobilities and the travel glance: Experiences of being on the move, Scandinavian Journal of Hospitality and Tourism 1 (2), 2001, 80-98.

Latham A., Research, performance, and doing human geography: Some reflections on the diaryphotograph, diary-interview method, Environment and Planning A 35 (11), 2003, 1993-2018.

Latham A. and McCormack D.P., Thinking with images in non-representational cities: Vignettes from Berlin, Area 41 (3), 2009, 252-262.

Lefebvre H., Rhythmanalysis: Space, time and everyday life, 2004, Continuum; London.

Li Y., Geographical consciousness and tourism experience, Annals of Tourism Research 27 (4), 2000, 863-883.

Lorimer H., Cultural geography: The busyness of being "more-than-representational”, Progress in Human Geography 29 (1), 2005, 83-94.

Macbeth D., On 'reflexivity' in qualitative research: Two readings, and a third, Qualitative Inquiry 7 (1), 2001, 35-68.

Maddison D., In search of warmer climates? The impact of climate change on flows of British tourists, Climatic Change 49 (1-2), 2001, 193-208.

Mansfeld Y., Freundlich A. and Kutiel H., The relationship between weather conditions and tourists' perception of comfort: The case of the winter sun resort of Eilat, In: Amelung B. and Viner D., (Eds.), Proceedings NATO advanced research on

climate change and tourism: Assessment and coping strategies, 2007, Warsaw; Poland, 116-138.

Martin G. and Belén M., Weather, climate and tourism a geographical perspective, Annals of Tourism Research 32 (3), 2005, 571-591.

Masberg B.A. and Silverman L.H., Visitor experiences at heritage sites: A phenomenological approach, Journal of Travel Research 34 (4), 1996, 20-25.

Massumi B., Parables for the virtual: Movement, affect, 2002, Duke University Press; Sensation. McCormack D.P., Engineering affective atmospheres on the moving geographies of the 1897 Andrée expedition, Cultural Geographies 15 (4), 2008, 413-430. 
Meethan K., Mobile cultures? Hybridity, tourism and cultural change, Journal of Tourism and Cultural Change 1 (1), 2003, 11-28.

Merleau-Ponty M., Phenomenology of perception, 1962, The Humanities Press; New York.

Merriman P., Rethinking mobile methods, Mobilities 9 (2), 2014, 167-187.

Mkono M., The othering of food in touristic eatertainment: A netnography, Tourist Studies 11 (3), 2011, 253-270.

Mkono M. and Markwell K., The application of netnography in tourism studies, Annals of Tourism Research 48, 2014, 289-291.

Mossberg L., Extraordinary experiences through storytelling, Scandinavian Journal of Hospitality and Tourism 8 (3), 2008, 195-210.

Obrador Pons P., Being-on-holiday tourist dwelling, bodies and place, Tourist Studies 3 (1), 2003, $47-66$.

Pernecky T. and Jamal T., (Hermeneutic) Phenomenology in tourism studies, Annals of Tourism Research 37 (4), 2010, 1055-1075.

Phelan P., Unmarked: The politics of performance, 1993, Routledge; London.

Pink S., Doing visual ethnography, 2007, SAGE Publications; London.

Rantala O. and Valtonen A., A rhythmanalysis of touristic sleep in nature, Annals of Tourism Research 47, 2014, 18-30.

Roy S. and Hannam K., Embodying the mobilities of the Darjeeling himalayan railway, Mobilities 8 (4), 2013, 580-594.

Scarles C., Becoming tourist: Renegotiating the visual in the tourist experience, Environment and Planning D Society and Space 27 (3), 2009, 465-488.

Scarles C., Where words fail, visuals ignite: Opportunities for visual autoethnography in tourism research, Annals of Tourism Research 37 (4), 2010, 905-926.

Schivelbusch W., The railway journey: The industrialization of time and space in the 19th century, 1986, University of California Press.

Scott M., The alchemyst, 2007, Delacorte Press; New York.

Shortt H., Sounds of the salon: The auditory routines of hairdressers at work, International Journal of Work Organisation and Emotion 5 (4), 2013, 342-356.

Shusterman R., Practicing philosophy: Pragmatism and the philosophical life, 1997, Routledge; New York. 
Simpson P., "Falling on deaf ears": A postphenomenology of sonorous presence, Environment and Planning A 41 (11), 2009, 2556.

Simpson P., 'So, as you can see...': Some reflections on the utility of video methodologies in the study of embodied practices, Area 43 (3), 2011, 343-352.

Sobchack V.C., The address of the eye: A phenomenology of film experience, 1992, Princeton University Press; New Jersey.

Tribe J., The art of tourism, Annals of Tourism Research 35 (4), 2008, 924-944.

Uriely N. and Belhassen Y., Drugs and risk-taking in tourism, Annals of Tourism Research 33 (2), 2006, 339-359.

Van Maanen J., Tales of the field: On writing ethnography, 1988, University of Chicago Press.

Vannini P., Ferry tales: Mobility, place, and time on Canada's West Coast, 2012, Routledge; New York

Vannini, P., Non-representational methodologies: Re-envisioning research, 2015, Routledge; New York.

Vannini, P. (n. d.). Non-representational theory and ethnographic research. Retrieved from http://ferrytales.innovativeethnographies.net/sites/default/files/Non-

Representational\%20Theory\%20and\%20Ethnographic\%20Research.pdf.

Vannini P. and Taggart J., Doing islandness: A non-representational approach to an island's sense of place, Cultural Geographies 20 (2), 2013, 225-242.

Waitt G. and Duffy M., Listening and tourism studies, Annals of Tourism Research 37 (2), 2010, $457-477$.

Waterton E., Landscape and non-representational theories, In: Howard P., Thompson I. and Waterton E., (Eds.), The Routledge companion to landscape studies, 2012, Routledge; London, 66-75.

Wylie J., Becoming-icy: Scott and Amundsen's South Polar voyages, 1910-1913, Cultural Geographies 9 (3), 2002, 249-265.

Wylie J., A single day's walking: Narrating self and landscape on the South West Coast Path, Transactions of the Institute of British Geographers 30 (2), 2005, 234-247.

Xiao H., Jafari J., Cloke P. and Tribe J., Annals: 40-40 vision, Annals of Tourism Research 40 (1), 2013, 352-385. 